\title{
Vendingens latter
}

\author{
Marianne Ping Huang
}

Han ønskede at spørge, om det legeme, de førte af sted imellem sig, var hans legeme - det vil sige det legeme, han var kommet for at hente - det vil sige for at hente en del af, eller rettere sagt om det legeme, de bragte ind ad sideindgangen, var liget af en nyligt afdød kvinde, der havde testamenteret sit legeme til videnskaben, og som derfor - det vil sige til dels - det vil sige for en brøkdels vedkommende - var udset til at føre videnskaben og dermed hele menneskeheden et skridt nærmere løsningen af den store gåde om menneskets oprejste stilling [...]

Nogle vil måske allerede genkende den lakonisk præcise stil - og dermed også den, der her ønsker at spørge, men aldrig får stillet sit prekære spørgsmål. $\mathrm{Vi}$ er ved indgangen til Solvej Balles Ifølge loven (1993), "Fire beretninger om mennesket". Den spørgende er Nicholas $S$. fra samlingens første beretning, om undersøgelsen af det - i grunden - mærkværdige, at mennesket er $i$ stand til at holde sig oprejst og i bevægelse over lange afstande. Nicholas S.'s undersøgelse er hverken antropologisk eller psykologisk, men biokemisk - og legemet, som bringes ind på Institut Médicolégal de Québec, skal forsyne ham med den hjernebark, hvor man forventeligt vil kunne isolere og bestemme et flygtigt stof, som vil krone hans tese med bevis. Ikke så underligt, at stilen er både kortåndet og kortfattet: Vi står ved et gennembrud i biokemiens udforskning af ét af vore artsspecifikke karakteristika. Hvilken vending gjorde en vandrende halvprimat til en homo erectus? Øjeblikket er afgørende og retarderes sigende i biokemikerens stammende vendinger; det udtales aldrig, men snubler i sig selv.

Momentet er - vil jeg hævde - både vittigt i sin formulering, komisk ved sin genstand og filosofisk $i$ sin indsigt; og alt $\mathrm{i}$ alt humoristisk $\mathrm{i}$ sin stoiske bredde. Det er også karakteristisk for Solvej Balles stil og tænkning som et kippefænomen mellem eksakt følge, platitude, brander og lynende indfald: Sætningen vender og drejer sig, og kipningens uafgørlighed er lattervækkende $i$ en forstand, som overskrider både situationskomikken, hvor biokemikeren snubler $i$ dét han aldrig fảr sagt, og det indsigtsfulde $i$, at vi så let følger den helt igennem logiske snublen og således selv går på halen.

\section{Omkring et legeme}

Stilens særegenhed ses først i den lille sekvens' forening af medsyn med Nicholas S.'s befippelse og befippelsens sprogligt præcise energi. Befippelsen selv er psykologisk, psykologien er monoman - han må ha' den hjerne for at bevise det menneskeligt artsspecifikke; altimens sproget som et andet artsspecifikt karakteristikum slår sludder og snubler på sin eksakte vej mod præcision. Ikke sådan, at det momentane nonsens forbliver sludder og vrøvl, men sådan at den vittige præcisering udfolder et logisk paradoks, et tertium datur, som netop ikke er sludder og vrøvl. Tværtimod er der tale om spidsformuleringen af kipninger og vendinger mellem flere logikker.

Man ser det allerede i den indledende præmis, "om det legeme, de førte af sted imellem sig, var hans legeme" (jeg fremhæver). Dobbelttydigheden $\mathrm{i}$ det possessive pronomen initierer vittigt sætningens hele paradoksi: Naturligvis er det ikke Nicholas S.'s legeme; han går jo dér bag båren. $\mathrm{Og}$ så ér det måske alligevel hans legeme. Hvis altså afdøde ér den kvinde, som han har fảet meddelelse om at afhente, fordi hun har testamenteret sig, altså sit legeme, til videnskaben.

Befippelsen ses $\mathrm{i}$ tankestregers indskæring og $\mathrm{i}$ det iterative slutningsled, 'det vil sige'. Begge dele nød- 
vendige for sætningens passion, men unødvendige for dens slutningskæde. Logikken er åbenlys, trods sætningens selvkorrektioner og følgende præciseringer på vej mod det korrekte spørgsmål. Nicholas S. vil erklære sit ganske bestemte ejendomsforhold til legemet på båren, som skal gøre det muligt for ham at udtage, nedfryse og bære en ganske lille del af afdøde til sit laboratorium. Men i denne eksakte hensigt, som må formuleres juridisk, blander sig videre spørgsmål om liv og død, om objekt og subjekt: Er dét på båren et legeme, et lig eller en afdød? Er dét en selvberoende enhed eller delbart stof, som kan distribueres ud i verden?

Følgerigtigheden på vejen til det udsagn, Nicholas S. aldrig når at ytre, er altså ganske korrekt, men implicerer også en uhørt blanding af love, som kolliderer hér, foran det retsmedicinske institut, hvor jura, patologi og biologi er ét og alligevel tre. På denne tærskel kipper Nicholas S. mellem passion og præcision, ligesom målet for begge affekter $\mathrm{i}$ hans uudtalte slutning, legemet, kipper mellem at være lig (et-ikke-længere-levende-stof) og afdød (et tidligere subjekt). Dette 'jeg' bag båren oscillerer mellem forskende grebethed og eksakthed, ligesom dette 'dét' på båren oscillerer mellem biologi og jura, mellem natur og kultur.

Blot er det ikke helt til at afgøre, hvor grænserne går - hverken i sætningens mange præcise vendinger eller $\mathrm{i}$ de bestandige vendinger hos læseren, som Balles absolutte humor tilsiger os at gøre med.

\section{Afhendelse - eller er der noget at grine af}

Spørgsmålet er naturligvis om Balles kippefænomen er morsomt? Og i givet fald, i hvilket omfang? Hvad ler vi af, hvis vi ler?

Nogle vil straks svare, at $n e j$, vi ler ikke rigtig. Det kan højst blive til et svedent grin. Paradokserne som impliceres er for seriøse til, at dette skulle være morsomt - for alvor. Moralsk korrekthed fjerner os her fra det radikale selvtab i sproget, som Baudelaire i "Om latterens væsen" (I855) ville kalde absolut komik, og i hvilken vi ville falde med biokemikeren, gennem alle hans vendinger. Sprogligt vid kan man imidlertid ikke frakende Solvej Balles afslørende formulering af, hvor monoman Nicholas S. er i op- tagetheden af sit projekt. Ved kun at læse dette vid som en fremvisning af biokemikerens eksistentielle forfaldenhed, bliver den jo alligevel komisk. Vi ler på afstand - af staklens fald i sine præmissers mærkværdige følge, men frakender dermed også viddet yderlige indsigtsgivende implikationer, som opstår, hvor der udfolder sig noget mere end en instrumentel diskurs (og det gør der jo netop her), og hvor vi derfor må tage sekvensens medsyn og parekbasis på os. Ved derimod at vide bedre, i netop det øjeblik vi ser Nicholas $S$. gå på halen, underbinder vi så at sige faldet $\mathrm{i}$ sproget ved den diskursive uoverensstemmelse. Og ér vi ikke netop biokemikere eller retsmedicinere forbliver sagen betydningskomisk: Godt man ikke er biokemiker!

Andre ville straks ved indgangen til Ifølge loven - og naturligvis ikke hér efter omstændelige manøvrer i vitsen - have svaret, at ja, hér må vi le; for slutningens affekter er alvorligt morsomme. Ikke alene vittige i den sprogligt elegante afsløring, som spiller på et spektrum fra formallogik til videnskabsetik; ikke alene komiske ved at vi således ser ind $\mathrm{i}$ biokemikerens logisk-argumentative sprogforbistring; men absolut komiske når vi ser, at forbistringerne er mere end specifikke, at noget alment og inhumant $i$ såvel det diskursive som sproglige udpeges, og at vi deltager $i$ dette alene ved at se det ske i slutningsrækken.

Latteren i Solvej Balles vendinger er absolut komiske i Baudelaires forstand; og dermed mere almenmenneskelig end specifikt bundet til et grin over den instrumentelle verden, som Nicholas S. repræsenterer. Læseren må - ved overhovedet at forstå vendingens betydningskomik - vende sig fra dennes begrænsende perspektiv og indse, at slutningens diskursive inkongruenser er mere end dét, nemlig også logiske og retoriske, simpelthen sproglige og dermed inden for en erkendelsesdimension, som rækker ud over forskellen mellem det instrumentelle og livsverdenen. I Nicholas S.'s befippede monomani, som den viser sig i kipningen mellem sætningens passionsmarkører (tankestreger og iterationer) og forsøgene på at præcisere sig, må man genkende monomaniens stil som en almen affektiv kipning mellem lidenskab og eksakthed, som vi alle (håber vi $\mathrm{da}$ ) kan hensættes $\mathrm{i}$. Vi undrer os da over 
sprogets dobbelttydigheder, og begiver os således med Baudelaires absolutte komik afsted i en uendelig parekbasis fra meningens - logikkens, retorikkens, lovenes højder - ned i en kompromisløs erkendelses dybde.

Fra konstateringen af, at der kan være betydningskomik på færde i Solvej Balles vittige slutningsrække, lader komikken sig altså udvide i mere almen retning. Fra det specifikke i Nicholas S.'s tilfælde til det almene, som angår 'mennesket', der jo overhovedet er undersøgelsens genstand i Ifølge loven. Blot står det nu tilbage at spørge til denne almenhed - hvor vidt kan vi gå med den, ifølge humoren?

\section{Sidste vending - eller fra vertikalt til horisontalt}

Er Ifølge loven med andre ord mere radikalt humoristisk i sin udforskning af det menneskelige, så den absolutte komiks latter - over at være både indfældet i og kastet ud af sprogets love - igen må vende sig? $\mathrm{Og}$ nu måske i en udadgående bevægelse, gennem det spind af lovkomplekser og lovmæssigheder omkring det legemlige, som vi har set være på færde $\mathrm{i}$ Nicholas S.'s slutning.

En sådan foreløbig sidste vending $i$ anledning af vort lille citat ville atter placere det menneskelige $\mathbf{i}$ en relation til sproget, dog nu ikke i en negation af, men $i$ en interferens med verden. Her gør latteren endnu en vending, fra et vertikalt svimlende, absolut komisk perspektiv ved sprogets afgrund til en lige så svimlende udbredelse af det menneskeliges forbindelser med verdens uafgørligheder. Dermed hører Nicholas S. og hans forbistring tillige op med at være repræsentative eksempler på snart den ene, snart den anden komik. I stedet fældes han og hans, vi og vort, $u d$ af et statuarisk forhold mellem essens og eksempel og ind mellem alle mulige andre singulære vendinger $i$ verden.

Hér udvides da indgangen til Balles humor, fra biokemikerens momentane snublen og den myopiske erkendelse af monomaniens humor til kredsen af beretninger, som udgør Ifølge loven. Humoren slår os bogstavelig bagfra, fra samlingens lige så urimelige og monomane fjerde og sidste beretning. Dén om Alette V., som vil være en ting - og næsten bli'r det. Dette 'dét' på båren formoder vi er Alette, der i bogstavelighed stræber mod at forbinde sig med verden. Hun mærker en forbindelse $i$ transporten af varme og kulde mellem sig og verdens ting, men forholder sig kølig over for menneskers interesse for individuation og følgelige forskrivelse til fællesskabets historie:

Hvis man ønskede det, kunne man her fă serveret drikke på landlig vis i store skåle i stedet for kopper. Alette V. holdt af at mærke udvekslingen af varme mellem sig og omgivelserne, og hun fandt cafeens store kulørte fajanceskåle af passende størrelse. Hun bemærkede, at den unge servitrice hurtigt og rutinemæssigt tog en af disse kulørte skåle frem, da hun bestilte kaffe, uden først at forhøre sig om sin kundes ønske.

Fortroligheden generede Alette V.

Er menneskets afhændelse af fællesskab og selvafhændende tilstedeværelse $\mathrm{i}$ verdens horisontale og fænomenale uoverskuelighed og udveksling, som Alette V's monomani koncentrerer sig om, komisk eller tragisk? Tydeligvis ingen af delene. Den er en bestemt måde at forstå skæbne som perceptiv indsigt: "Dette var hvad. Alette V. forstod ved ordet skæbne. Verdens tilfældige indbrud i de menneskelige sanser. Ikke en hemmelig styrende hånd eller en nøje tilrettelagt plan, men en simpel bevægelse, der genkendes fra utallige beretninger om menneskets indsigt $\mathrm{i}$ tingenes verden." Sådan en simpel bevægelse mellem menneske og verden overgår Alette V., mens hun drikker kaffe af en kulørt fajanceskål, af en eksakt passende størrelse - til netop indsigten $i$, at hendes overgang fra menneske til ting må ske gennem afkøling: "Alette V. behøvede ingen oprivende gestus. Hun åbnede roligt sit vindue. Hun følte ikke kulden mod sin afklædte krop. Hun bemærkede dens virkning."

Alette V.'s selvmord - eller passage til ting - ved god champagne og frostluft skriver hende ikke ud af den sprogligt absolutte og diskursivt relative komik, netop fordi hun både 'går over' (som det også hedder $\mathrm{i}$ visse religiøse sekter) og begår selvmord. Hun kan kun blive objekt ved at være subjekt, endda et suverænt, viljestærkt og monomant subjekt og der- 
for i grunden særlig egnet for anekdotens vits: 'Der var engang en kvinde i Québec, som ville være en ting...' Tilmed overgør Alette V. den suveræne handlen med sit legeme, idet hun testamenterer det til permanent objektgørelse ved dissektion og udstilling, disjecta membra, i formaldehyd. Situationskomisk lykkes planen naturligvis ikke. Dødsårsagen er juridisk uklar, skønt så eksakt, og afdøde må derfor i stedet for at blive dissekeret, ifølge Loven om ligsyn, obduceres - og så er det hele ødelagt, for da kan man ikke komme på glas. Derfor ambulancen og båren ved indgangen til Institut Médicolégal de Quebéc.

Lige hér er det Nicholas S., 97 sider forinden, er løbet efter mangetydigheden på båren: legeme, lig, afdød; ting, stof, energi - eller hvad? Ved mellemkomst af Nicholas S.'s ræsonnement, som sprogligt præcist (og faktisk uden medviden i Alette V.'s specifikke tilfælde) både viser os det paradoks, hun udgør $i$ verden, implicerer os $i$ dets absolutte komik og vikler os ind love og lovmæssigheders spind, udvides humóren hos Balle. Fortælleteknisk, naturligvis, $i$ en cirkel- eller spiralbevægelse fra slutningen til begyndelsen af Ifølge loven, men især ved at udbrede perspektivet fra sprogets immanente dobbelttydighed til dobbelttydighederne som en given - og for eftertanken indsigtsfuld - refleks af verdens systematiske og inhumane uafgørlighed. Denne sidste kipning sker fra det vertikalt komiske i Nicholas S.'s enkeltstående og sigende formulering til en horisontal, humorfyldt mere-sigen, som imidlertid ikke når os som et eksplicit udsagn om interferensen. Dét udsagn ytres lige så lidt, som Nicholas S. får sit spørgsmål formuleret. Men det ligger følgerigtigt spredt ud i en række vendinger i og imellem de fire beretninger, ja, i det hele taget i Solvej Balles seismografiske sans for de små rystelser mellem sprog og verden.

Denne sans, som er en stor og absolut humor, bevæger sig hos Balle på tværs af branderen, vitsen, indfaldet og ironien, på tværs af komikkens relative eller absolutte modi; på tværs af anekdoten, fortællingen, beretningen i Ifølge loven - og til kortformerne $\mathrm{i}$ andre, lige så væsentlige dele af det lille, yderst koncentrerede forfatterskab. Andre eksempler på latterens vending i en vidtgående og stoisk udbredelse kan man hente i Solvej Balles prosalyriske suite, Eller (1998), der indledes: "I efteråret er vendingen sket". Suiten besvarer i sine ikke-fortællende kortformer den berettende suite i Ifølge loven gennem en krystalklar konstellation, og drejer sig, som titlen siger, om forskelle og relationer. Herved besvarer den tillige $\mathcal{E}$ (x990), en isomorf suite om ligheder og relationer.

På Eller's 37 sider, med små stykker og stor sats, bredes et spektrum ud, fra formallogikkens lære om disjunktioner over det forskelsskabende faktum, at "[d]et ikke er ordene, der mangler, men lovene for deres anvendelse" til den fænomenale forskel mellem menneskers bevægelse fra huse og havers levede rum til sten og andre firkanter på kirkegårdene og det fossilfyldte skifers bevægelse fra stenbrud til gravsten og knasende grus på gravpladsernes gange. Et sidste, ukommenteret eksempel på latterens vending drejer sig - $\mathrm{i}$ en suveræn tætforing af nærhed og afstand $\mathrm{i}$ verdens udbredte liv og bevægelse igen om menneskets artsspecifikke karakter:

Vi lever af forskelle. Vi finder forråd i poser og æsker. Vi skærer kød eller grønt. Det er ikke nogen, vi kender. Vi anretter fade med andre arter end os. Skåle med frugter og rødder.

Følgende tekster var på færde:

Solvej Balle: $\mathcal{E}, \mathrm{Kbh}$. I990; Ifølge loven, Kbh. I993; Eller, Kbh. I998

Charles Baudelaire: “Om latterens væsen” (I855), Passage I7, Århus I994

Solveig Damgaard: "Kølig genrekonstruktion. En selektiv præsentation af Solvej Balles forfatterskab", Danske Noter 2, Kbh. 1999

Gilles Deleuze: “Om humor" (Logique du sens, r969), Passage 17 , Århus 1994

Sigmund Freud: Vitsen og dens forhold til det ubevidste (1905), Oslo r994

Eleonore Frey: "Lichtenbergs Einfälle", MLN ııo, John Hopkins UPr995

Marianne Ping Huang: "Hvordan noget romanagtigt foldes ud af beretningen. Om nøgternhed og tilfælde i Solvej Balles Ifølge loven", in: Perspektiver $i$ nyere dansk litteratur, Kbh. 1997

Henrik Madsen og Agnes Witzke: "Ifølge Solvej Balle", Danske Noter 3, Kbh. I995

Luigi Pirandello: Om humor (r908), Oslo 1994 